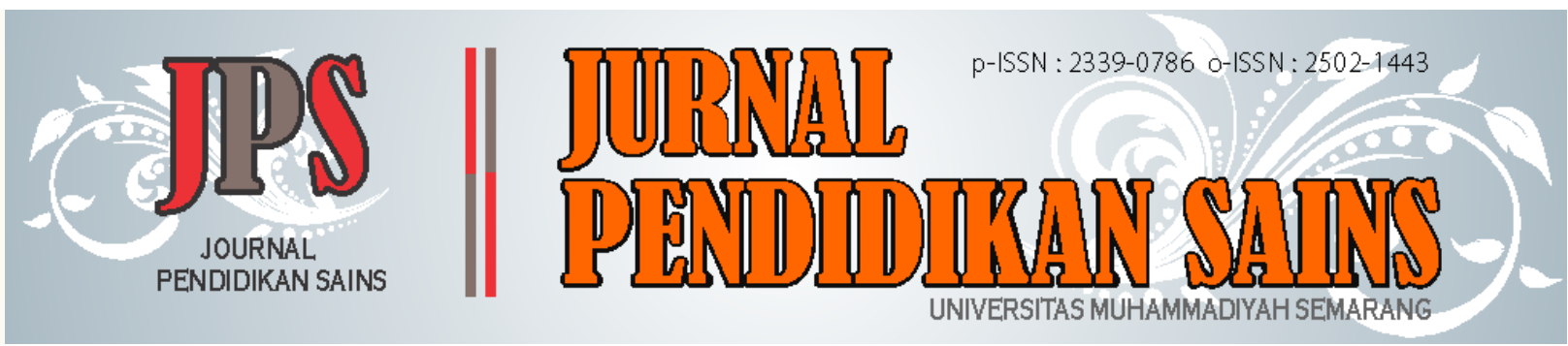

\title{
The Effect of Distance Learning Practicum based on PhET Interactive Simulations on Science Process Skills of Secondary School Students
}

\author{
Nur Efendi ${ }^{a, 1, *}$, Septi Budi Sartika ${ }^{\text {b,2 }}$ \\ ${ }^{\mathrm{a}, \mathrm{b}}$ Prodi Pendidikan IPA, Fakultas Psikologi dan Ilmu Pendidikan, Universitas Muhammadiyah Sidoarjo, \\ Jalan Mojopahit 666 B Sidoarjo, Sidoarjo 61215, Indonesia \\ ${ }^{1}$ nur.efendi@umsida.ac.id; ${ }^{2}$ septibudi1@umsida.ac.id* \\ * corresponding author
}

\begin{tabular}{lc}
\hline \multicolumn{2}{l}{ Article history } \\
\hline Submission & $: 2021-02-26$ \\
Revised & $: 2021-03-29$ \\
Accepted & $: 2021-04-18$
\end{tabular}

Keyword

distance learning practicum

PhET interactive simulation

science process skills

secondary school student's

\begin{abstract}
The condition of the covid-19 pandemic makes face-to-face learning become distance learning; learning activities from home are no exception to practicum learning - alternative solutions using PhET Interactive Simulations. The research aims to describe the influence and significant influence of PhET Interactive Simulation-based distance practicum learning on the science process skills of junior high school students. The research method uses quasiexperimentation with a matching pre-test post-test control group design. The research population is grade VIII students of SMP Sepuluh Nopember Sidoarjo with a sample of 2 grade VIII, namely VIII H as an experimental class and VIII $\mathrm{F}$ as a control class of 40 students each. Research instruments use science process skills tests with seven indicators: formulating problems, formulating hypotheses, identifying variables and operational definitions of variables, assembling tools and materials, presenting data, conducting data analysis, and concluding. The results showed a considerable influence between distance learning practicum based on PhET interactive simulations on the science process skills of secondary school students in natural science subjects. Further research increases the number of research variables and science process skills as well as an understanding of student concepts to science, and so on.
\end{abstract}

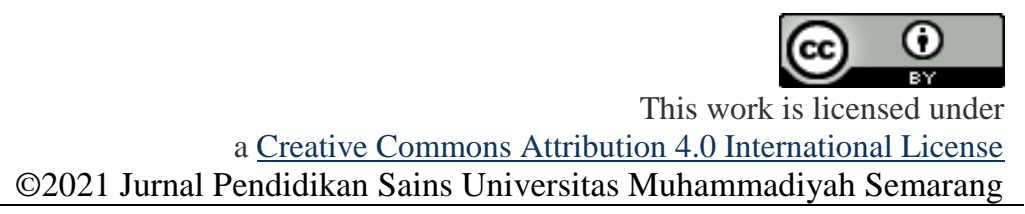

\section{INTRODUCTION}

Natural Sciences consists of scientific attitudes, scientific processes, and scientific products (Susilowati, 2017). The three are sustainable and inseparable from each other. Through scientific attitudes, a character will be formed as the basis in conducting scientific processes. The scientific process is a scientific method or scientific steps that will produce scientific products so that by integrating the three, the resulting scientific products can be accounted for. With these scientific products, it will be able to apply them in various other fields, such as technology, economics, education, etc.

In the field of education, one of the scientific products is the development of the curriculum. According to Ibrahim (2012), a curriculum is a set of subjects and educational programs organized by 
educational institutions that contain learning plans given to students in a certain period. The current school curriculum is Curriculum-2013. In Curriculum-2013, the core competencies consist of 4 (four), namely spiritual attitudes, social attitudes, knowledge, and skills (Nuh, 2013). All four are holistically instilled through a scientific approach. Scientific approaches include observing, questioning, trying, reasoning, and communicating (Sani, 2014). This approach is used to train all subjects in the school, including science subjects.

Based on the observations and interviews with the natural science teachers of SMP Sepuluh Nopember Sidoarjo, natural science subjects and delivering materials also require practicum to prove the truth of the theory that has been delivered. During the covid-19 pandemic, face-to-face practicum cannot be done because there is an appeal from the Minister of Education that as of March 26, 2020, learning will be conducted from their homes. This is done to stop the transmission of covid-19. The appeal is still ongoing today. With these conditions in mind, teachers need to change the strategy of face-to-face practicum learning by replacing remote practicum, which can be done online or offline.

Practicum is an essential activity for students, including practicum can arouse students' learning motivation, develop basic skills of experimenting, as a learning vehicle through a scientific approach, and support the subject matter. This is relevant to the results of Suryaningsih's research (2017); practicum learning activities can develop physical skills and social skills and be a means for students to practice implementing science process skills. According to Mahmudah (2016), the advantages of the process skills approach include students directly engaging with natural objects to facilitate understanding of the subject matter; learners find their concepts learned, train learners to think more critically, train learners to ask questions, and engage more actively in learning, encourage learners to discover new concepts, and allow students to learn using scientific methods. Thus, students' science process skills can be revealed through practical learning, in the condition of the covid-19 pandemic is more precisely using remote practicum as an alternative solution.

The remote practicum in question is practicum activities that use virtual laboratories online and offline where interactions between teachers and students are conducted not directly through coordination with social media applications. There are many obstacles in conducting remote practicum, among which is less maximal in coordination between teachers and students because most of the independent work is not in groups, then network constraints, and the availability of devices such as laptops / PCs. This is by the results of sari research et al. (2020). Distance learning still has many obstacles, such as inadequate equipment and a poor internet connection. The increase in learning success is still tiny and ineffective.

An alternative virtual laboratory used for remote practicum is phet interactive simulations. PhET stands for Physics Education Technology, an online and offline-based simulation developed by Wieman from the University of Colorado. Simulations include Physics, Chemistry, Mathematics, Earth Sciences, and Biology. PhET is equipped with teaching materials, application procedures, and levels ranging from elementary school to higher education. Astuti and Handayani's research (2018) showed that PhET is very effective for experimental analysis. Furthermore, Pratama and Nana (2020), PhET can be applied in Thermodynamic learning as an alternative to virtual experiments. Researchers are interested in describing the influence and significance of distance practicum learning on the science process skills of secondary school students in science subjects.

\section{METHOD}

The research method uses quasi-experimental research with a pre-test post-test control group design (Fraenkel \& Wallen, 2012). The population is grade VIII students of SMP Sepuluh Nopember Sidoarjo with a sample of class VIII-H as an experimental class and class VIII-F as a control class. Data collection techniques using tests. Tests are systematic and objective tools or procedures for obtaining the desired data or information about a person in a way that can be said to be fast and precise (Arikunto, 2017). Research instruments use science process skills tests that refer to seven indicators: formulating problems, formulating hypotheses, identifying variables and operational definitions of variables, assembling tools and materials, presenting data, conducting data analysis, and concluding (Nur, 2011). Data analysis techniques using inferential statistics with t. The stages of research are as follows: 


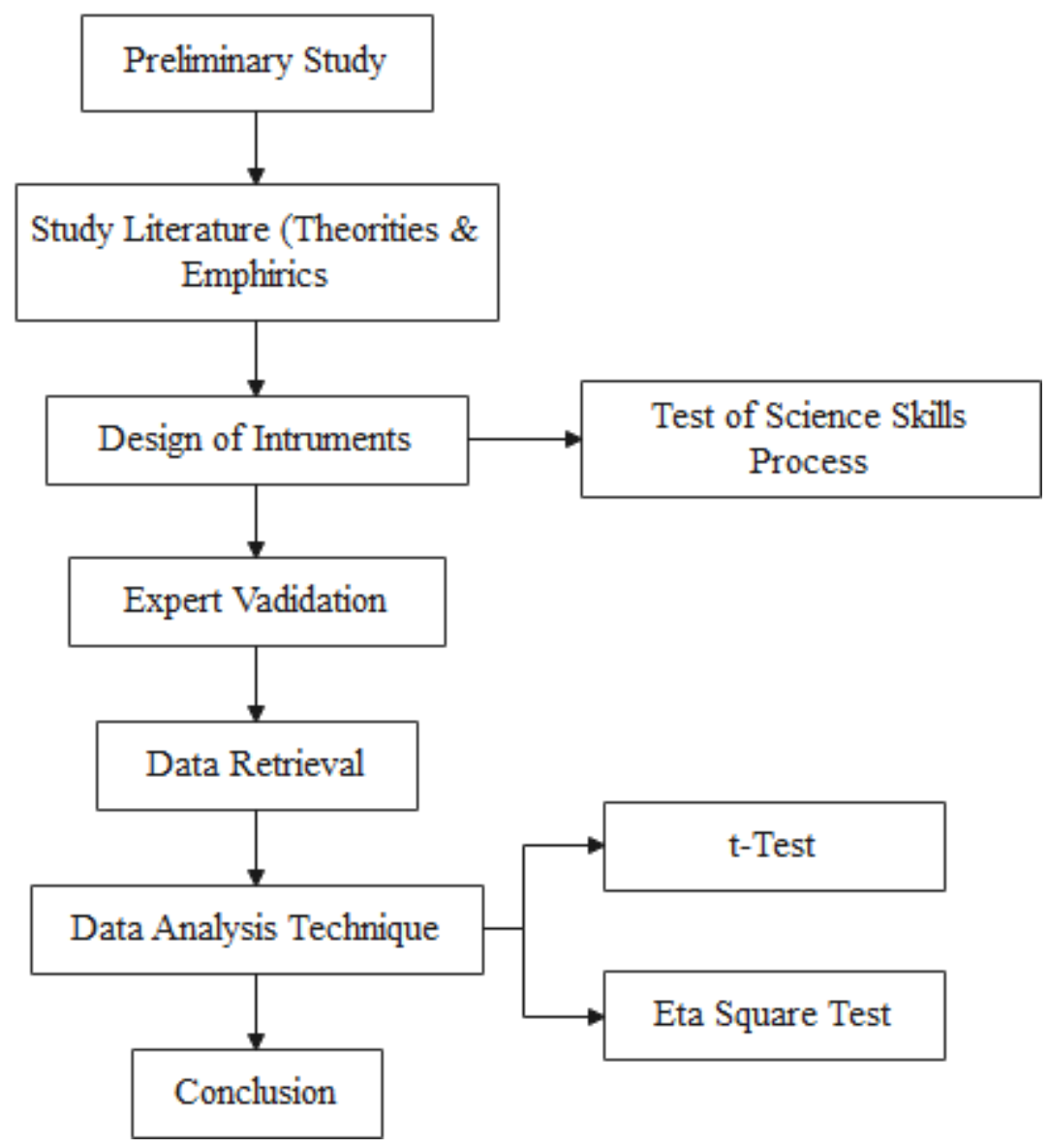

Figure 1. Research Stage

Based on Figure 1, the research phase starts from preliminary studies, literature studies (theoretical and empirical), design of research instruments, validation of research instruments by experts, data retrieval, data analysis, and research conclusions. Preliminary studies were conducted by conducting observations and interviews with one teacher of science learning activities in schools during the covid-19 pandemic, learning activities from home, and practicum that became part of science learning no longer done when the practicum can not be separated from IPA itself. By looking at these problems, researchers provide alternative solutions to phet-based remote practicum learning interactive simulations. Various theoretical and empirical studies state that PhET is effectively used as a virtual practicum, not only online can offline. The researchers then devised a test instrument to describe students' science process skills through PhET. Instruments are expertly validated until they are declared valid and eligible to be used (Kitagawa, 2015) to uncover students' science process skills. If the instrument is suitable for use, then the data is taken using quasi-experiment research design pre-test control group design. Both classes were conducted initial tests of science process skills. Practicum activities are carried out on vibration and wave materials, including three practica, namely simple pendulum, waves on the rope, and sound waves. The experimental class uses the phET interactive simulations, while the control class uses tools and materials that can be found in everyday life. The next stage of both classes is given a final test. Data obtained from both experimental and control classes is the value of science process skills. Data analysis was conducted to test the influence and magnitude of the influence of PhET Interactive Simulation-based distance practicum learning on the science process skills of secondary school students. The conclusion is obtained by analyzing the results of the t-test and eta square test. 


\section{RESULTS AND DISCUSSION}

Based on the results of t-test through SPSS paired samples test obtained:

Table 1. Paired Samples Test

\begin{tabular}{|c|c|c|c|c|c|c|c|c|c|}
\hline \multicolumn{7}{|c|}{ Paired Differences } & \multirow[b]{3}{*}{$\mathbf{t}$} & \multirow[b]{3}{*}{ df } & \multirow{3}{*}{$\begin{array}{l}\text { Sig. }(2- \\
\text { tailed) }\end{array}$} \\
\hline & & \multirow[b]{2}{*}{ Mean } & \multirow{2}{*}{$\begin{array}{c}\text { Std. } \\
\text { Deviation }\end{array}$} & \multirow{2}{*}{$\begin{array}{l}\text { Std. } \\
\text { Error } \\
\text { Mean }\end{array}$} & \multicolumn{2}{|c|}{$\begin{array}{l}\text { 95\% Confidence } \\
\text { Interval of the } \\
\text { Difference }\end{array}$} & & & \\
\hline & & & & & Lower & Upper & & & \\
\hline Pair 1 & $\begin{array}{l}\text { Pre Test (C) - } \\
\text { Post Test (C) }\end{array}$ & -12.87500 & 8.61182 & 1.36165 & -15.62919 & -10.12081 & -9.455 & 39 & .000 \\
\hline Pair 2 & $\begin{array}{l}\text { Pre Test }(E)- \\
\text { Post Test }(E)\end{array}$ & -8.30000 & 7.98781 & 1.26298 & -10.85463 & -5.74537 & -6.572 & 39 & .000 \\
\hline
\end{tabular}

Based on table 1, the same level of significance is obtained for both experimental and control classes of 0.000 and 0.000 , respectively, meaning that there is an influence of PhET interactive simulation-based distance practicum learning on the science process skills of junior high school students. Based on table 1, eta square calculation obtained a value of 0.52 means that distance practicum learning based on PhET Interactive Simulations has a significant impact on the science process skills of secondary school students in natural science subjects.

This is in line with Wahyudi and Supardi's research (2013), based on observing all aspects of science process skills obtained criteria good enough to improve student learning outcomes. Dewi et al. (2017) showed there was an improvement in the skills of the science process on all indicators. Similarly, Yuliati's research (2016) showed that science process skills improved better than the control class with moderate category. Thus, it can be said that there is a significant category improvement for science process skills through PhET-based distance practicum interactive simulations.

Natural science is one of the lessons closest to practicum. Through the practicum, the theory presented in learning can be proven to be true. In the event of the covid-19 pandemic, practicum cannot be done directly in the laboratory, so it requires a virtual laboratory to perform practicum activities, one of which is with phet application. The results of Saputra research et al. (2019), a PhET-assisted science learning tool that is valid, practical, and effective, can train science process skills. In practical learning, learning tools are needed. Thus, teachers' readiness in implementing PhET also needs to be considered for the effectiveness of practicum learning itself. According to Damayanti (2019), factors that influence the implementation of practicum are the readiness of teachers and students to carry out practicum, laboratory, tools and practicum materials, learning time, and labor. By preparing learning tools and factors that affect the implementation of practicum, practicum learning will run well.

The results of research on distance practicum learning conducted, teachers and students coordinate through WhatsApp Group, including the delivery of teaching materials, application links used if desired online, file downloads practicum eyes used if you want offline with the condition of installing java software applications. For science subjects, there are physical, chemical, and biological options according to the practicum subjects determined by the teacher. Completion of worksheet/ teaching materials is done with a maximum time limit of 1 week. Teachers evaluate the achievement of science process skills ranging from formulating problems, formulating hypotheses, identifying variables and operational definitions of variables, assembling tools and materials, presenting data, conducting data analysis, and concluding using science process skills tests. Yuliana research results (2017), the utilization of science laboratories can increase students' learning motivation and improve students' learning outcomes in biology learning. 
The following are presented the results of the science process skills test based on indicators:

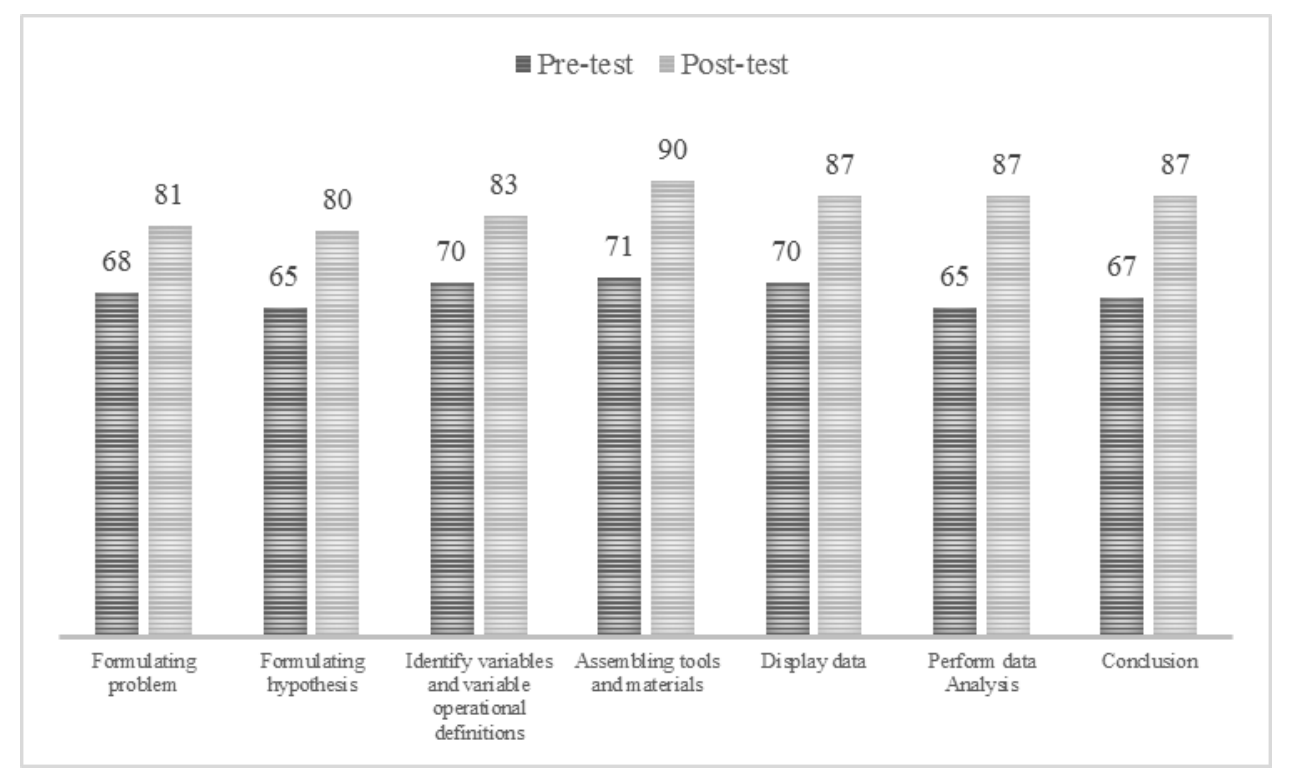

Figure 2. Science Process Skills by Indicators

Based on Figure 2, it was obtained that from the seven indicators of science skills implemented in science subjects improved. The highest increase in indicators performs data analysis, while the lowest increase in indicators formulates problems. Overall, from the calculation of N-gain obtained, there was an increase of 0.72 with a high category. This is by the results of the study of Putri et al. (2018) that learning with the application of PhET simulation-assisted inquencing models can improve the science process and mastery of the concept of light waves. Yunita et al. (2017) guided sequencing-based science learning tools supported by PhET media to improve students' science process skills. Safarati (2017), students' science process skills taught by scientific inquiry models using PhET media are better than students taught with direct instruction learning. Mauliana and Kustijono (2017), physics learning by practicing phet media is very effective and can improve students' science process skills the positive response from students shows it. Thus, practical learning with PhET media can improve students' science process skills and be viewed better than direct learning methods.

\section{CONCLUSION}

Based on the results and discussion, it can be concluded that there is a massive influence between phet-based remote practicum learning interactive simulations on the science process skills of junior high school students in science subjects. Based on the highest indicators of science process skills is to perform data analysis, while the lowest indicator is to formulate problems. Further research is expected to measure other research variables that also affect students' science process skills, such as the application of laboratory-based learning models combined with PhET or through other virtual laboratory applications.

\section{ACKNOWLEDGMENT}

The writing team expressed its gratitude to the Dean of the Faculty of Psychology and Education, University of Muhammadiyah Sidoarjo, Head of Science Education, friends of science education lecturers who have provided support and passion in writing as well as laboratory assistant students who have helped the author in collecting data in the field as well as all academic community of Muhammadiyah Sidoarjo University who have provided support to lecturers to write and write.

\section{REFERENCES}

Arifin, Z. (2020). Metodologi Penelitian Pendidikan. Jurnal Al-Hikmah, 1(1).

Astuti, I. A. D., \& Handayani, S. (2018). Penggunaan Virtual Laboratory berbasis PhET Simulation Untuk Menentukan Konstanta Wien. Jurnal Penelitian Pembelajaran Fisika, 9(2). 
Damayanti, N. K. A., Maryam, S., \& Subagia, I. W. (2019). Analisis Pelaksanaan Praktikum Kimia. Jurnal Pendidikan Kimia Undiksha, 3(2), 52-60.

Dewi, E. P., Suyatna, A., Abdurrahman, A., \& Ertikanto, C. (2017). Efektivitas Modul dengan Model Inkuiri untuk Menumbuhkan Keterampilan Proses Sains Siswa pada Materi Kalor. Tadris: Jurnal Keguruan dan Ilmu Tarbiyah, 2(2), 105-110.

Fraenkel, J. R., Wallen, N. E., \& Hyun, H. H. (2012). How To Design And Evaluate. Education research. Mc. McGraw-Hill.

Hake, R. R. (2002). Relationship Of Individual Student Normalized Learning Gains In Mechanics With Gender, High-School Physics, and Pretest Scores on Mathematics and Spatial Visualization. In physics education research conference (Vol. 8, No. 1, pp. 1-14).

Ibrahim, R. (2012). Kurikulum dan pembelajaran. Jakarta: Rajagrafindo Persada.

Kitagawa, T. (2015). A Test For Instrument Validity. Econometrica, 83(5), 2043-2063.

Mahmudah, L. (2017). Pentingnya pendekatan keterampilan proses pada pembelajaran IPA di Madrasah. ELEMENTARY: Islamic Teacher Journal, 4(1).

Maulina, R. N., \& Kustijono, R. (2017). Efektifitas pembelajaran fisika berbantuan media virtual PhET disamping pelaksanaan lab riil untuk melatihkan keterampilan proses sains. In Prosiding Seminar Nasional Fisika (SNF) (Vol. 1, pp. 65-69).

Nuh, M. (2013). Kurikulum 2013. Sumber: http://www. kemdiknas. go. id.

Nur, Mohamad. (2011). Modul Keterampilan-keterampilan Proses Sains. Surabaya: UNESA University Press.

Putri, E. M. E., Koto, I., \& Putri, D. H. (2018). Peningkatan keterampilan proses sains dan penguasaan konsep gelombang cahaya dengan penerapan model inkuiri berbantuan simulasi phet di kelas xi mipa e sman 2 kota bengkulu. Jurnal Kumparan Fisika, 1(2 Agustus), 46-52.

Safarati, N. (2017). Efek Model Scientific Inquiry Menggunakan Media PhET dan Keterampilan Berpikir Kritis Terhadap Keterampilan Proses Sains Siswa SMA(Doctoral dissertation, UNIMED).

Sani, R. A. (2014). Pembelajaran Saintifik untuk implementasi kurikulum 2013.

Saputra, T. B. R. E., Nur, M., \& Purnomo, T. (2019). Pengembangan Pembelajaran Inkuiri Berbantuan PhET untuk Melatihkan Keterampilan Proses Sains Siswa. Journal of science Education And Practice, 1(1), 20-31.

Sari, W., Rifki, A. M., \& Karmila, M. (2020). Analisis Kebijakan Pendidikan Terkait Implementasi Pembelajaran Jarak Jauh Pada Masa Darurat Covid 19. Jurnal Mappesona, 2(2).

Suryaningsih, Y. (2017). Pembelajaran berbasis praktikum sebagai sarana siswa untuk berlatih menerapkan keterampilan proses sains dalam materi biologi. BIO EDUCATIO:(The Journal of Science and Biology Education), 2(2).

Susilowati, S. (2017). Pengembangan bahan ajar IPA terintegrasi nilai Islam untuk meningkatkan sikap dan prestasi belajar IPA siswa. Jurnal Inovasi Pendidikan IPA, 3(1), 78-88.

Wahyudi, L. E., \& Supardi, Z. A. (2013). Penerapan model pembelajaran inkuiri terbimbing pada pokok bahasan kalor untuk melatihkan keterampilan proses sains terhadap hasil belajar di SMAN 1 Sumenep. Inovasi Pendidikan Fisika, 2(2).

Yuliana, Y., Hala, Y., \& Taiyeb, A. M. (2017). Efektifitas Penggunaan Laboratorium Terhadap Motivasi dan Hasil Belajar IPA Peserta Didik SMPN 3 Palakka Kabupaten Bone. Jurnal Nalar Pendidikan, 5(1), 39-45.

Yuliati, Y. (2016). Peningkatan keterampilan proses sains siswa sekolah dasar melalui model pembelajaran berbasis masalah. Jurnal Cakrawala Pendas, 2(2).

Yunita, Y., Poedjiastoeti, S., \& Agustini, R. (2017). Pengembangan perangkat pembelajaran IPA model inkuiri terbimbing ditunjang media PhET untuk meningkatkan keterampilan proses sains siswa. JPPS (Jurnal Penelitian Pendidikan Sains), 7(1), 1407-1415. 